\title{
António Feliciano de Castilho, cronista de um século tão destruidor como criador
}

\author{
António Feliciano de Castilho, chronicler of a century as destructive as creator
}

\author{
EDUARDO DA CRUZ \\ Universidade do Estado do Rio de Janeiro
}

Dr

\begin{abstract}
Resumo: António Feliciano de Castilho (1800-1875), reconhecido como poeta, também teve importante atuação no meio jornalístico. Como redator da Revista Universal Lisbonense entre janeiro de 1842 e junho de 1845, ele transformou o projeto editorial familiar num periódico de sucesso, vendido e assinado em todo Portugal e também no Brasil. Além de divulgação de "conhecimentos úteis" e de novas composições literárias, sua revista possuía uma seção de notícias. Nesse espaço, Castilho transformava os relatos dos casos que recebia em crônicas que deixam transparecer seu olhar sobre a sociedade que se transformava em meados do século XIX. Aqui apresentamos alguns dos principais temas e o estilo de construção de suas crônicas.

Palavras-chave: Crônica; Imprensa Periódica; Violência; Revista Universal Lisbonense; Liberalismo

Abstract: António Feliciano de Castilho (1800-1875), recognized as a poet, played also an important role in the journalism. As editor of Revista Universal Lisbonense between January 1842 and June 1845, he turned the family project into a publishing success, sold and signed across Portugal and even Brazil. In addition to the publication of what was called "useful knowledge" and new literary compositions, his magazine had a news section. In this space, Castilho transformed in chronicles the reports of cases received in the newsroom. These texts bring his gaze upon the society in transformation in the mid-nineteenth century. Here are some of the main themes and style of construction of his chronicles.
\end{abstract}

Keywords: Chronic; Periodical Press; Violence; Revista Universal Lisbonense; Liberalism

Este século, tão destruidor como criador, matou a Livraria, e pôs em seu lugar o Jornalismo. Assim devia de ser, porque este século é popular. ${ }^{1}$

(Programa da Revista Universal ${ }^{2}$ )

António Feliciano de Castilho ficou marcado na história da literatura como "árcade-póstumo", epíteto criado pela Geração de 70 para menosprezar sua produção poética e olvidar seu nome. Contudo, não é possível deixar de reconhecer sua importância no sistema literário da época, a ponto de Ida Alves, ao analisar as cartas desse poeta para Camilo Castelo Branco, afirmar que "mesmo que hoje seja considerado um escritor menor, não se pode simplesmente apagar sua existência 'verbal' nesse século tão rico de mudanças sociais, políticas, econômicas e históricas" (2014, p. 12).

\footnotetext{
Optamos por atualizar a ortografia para aproximar um autor esquecido do público contemporâneo.

2 Recreio, n. 8, ago. 1841, p. 182.
}

Ao percorrermos a atuação de Castilho na imprensa, mais especificamente como redator da Revista Universal Lisbonense ( $R U L)$, cargo que desempenhou entre janeiro de 1842 e junho de 1845, encontramos também esse escritor "com certa habilidade de cativar o leitor pelo tom 'conversador', pela ironia ou humor e pela atenção aos fatos e novidades, encantado sempre pelas invenções ou modas que vão eclodindo na sua contemporaneidade" (ALVES, 2014, p. 12), sobretudo nas crônicas publicadas nesse periódico. Acompanhando as notícias que enchiam as páginas de sua revista (só o filho reeditou 237 nos 7 volumes de Casos do Meu Tempo), percebe-se que os assuntos agrupam-se em algumas temáticas que estão associadas a seu projeto como jornalista. O editor desses volumes indicava, em 1906, que coube a esse semanário 
"inaugurar a crónica cidadã, a pintura diária dos usos e costumes, o apontamento fugitivo, que tanto vem a servir às estatísticas criminais, e à galeria do viver das famílias" (1906, p. 7-8).

$\mathrm{O}$ assunto predominante é mesmo a violência, mas podemos perceber outros temas majoritários, como as transformações urbanísticas em Lisboa, que alteravam o modo de vida; os excessos de sentimentalismo e de subjetividade, que o estilo moderado de Castilho não aceitava; e os combates abertos pela civilização, contra enganos, superstições, injustiças e barbáries. Essas crônicas não são apenas portadoras de visões sobre um acontecimento, mas veículos que intervinham nos processos e episódios de seu tempo. Certeau diz que escrever "é uma atividade concreta que consiste, sobre um espaço próprio, a página, em construir um texto que tem poder sobre a exterioridade da qual foi previamente isolado" (1998, p. 225). Portanto, escrever tem como função influir sobre a realidade, da qual se distingue, com o objetivo de transformá-la, algo que Castilho percebia claramente.

No caso das crônicas, elas partem de assuntos variados da realidade cotidiana. Barthes indica que "não há fait divers sem espanto (escrever é espantar-se)" (1970, p. 60). Não é difícil imaginar o quanto António Feliciano de Castilho ter-se-ia espantado ao escrever as notícias para sua folha semanal. Seu irmão, José Feliciano, ao abrir essa seção na reformulação que a Revista sofre em março de 1842, relata preocupado que "pacífica não corre a idade em que vivemos" (RUL, II, n. 25, 09 mar. 1843, p. 294). Ele estava se referindo a todas as revoluções, revoltas, golpes, guerras, etc. que marcaram a Europa e as Américas desde o fim do século anterior. António Feliciano, formado imaginando uma vida na Roma antiga e recluso por anos em Castanheira do Vouga, deveria sentir essa tensão violenta como algo que ocorria a distância, mesmo que a casa paroquial de seu irmão tenha servido de refúgio a grupos liberais durante a guerra civil que opôs absolutistas e liberais. Todavia, o que se vivia nos primeiros anos após a guerra deveria ser bem diferente do que ele desejaria para a Lisboa liberal. O que fazer? José Feliciano terminou seu texto de abertura desejando que cada estado cumprisse sua missão. "Oxalá que a nossa seja a da paz, da fraternidade, do progresso, e que não envergonhemos a Providência a ter-nos liberalizado os seus mais mimosos dons" (RUL, II, n. 25, 09 mar. 1843, p. 296).

O mundo estava em transformação após as revoluções liberais, e a paisagem de Lisboa mudava também. Por todo lado, edificações iam abaixo para que novas surgissem e essas alterações urbanísticas modificavam a vida de algumas comunidades. Castilho pinta ainda o viver de um dos pátios existentes entre a Baixa e o
Bairro Alto, modelo de comunidade que ele via desaparecer:

São os pátios uma espécie de ilhas encobertas, que ainda se encontram (posto já foram em maior número) no meio deste mare magnum de ruas e gente, chamado capital. Raras pessoas conhecem dos pátios mais do que o nome e quando muito o arco ou porta externa de algum deles: são os verdadeiros mistérios de Lisboa. Num labirinto mais ou menos amplo de barracas, paredeiros, pocilgas, ruínas e entulhos, vive um formigueiro humano, onde a miséria, o vício e o crime se revezam, se perpetuam, e permutam entre si os seus reflexos escuros e aborrecidos - ali o sol não penetra senão a custo; a civilização nada; a religião com a tumba, e a polícia em algum caso extremo. São em menor ponto mas são as Cour des miracles de Victor Hugo e Alsace de Walter Scott (RUL, IV, n. 32, 27 fev. 1845, p. 389).

Nota-se que Castilho não lamenta a destruição dos pátios. A esses espaços ele associa uma literatura romântica negra, de mistério, de superstição, também onde "o sol não penetra", tal como ele narra nessa "Tragicomédia num pátio". Um judeu tinha "uma mocetona" com quem vivia bem. Contudo, um dia, "cansado da sua felicidade, ou embelecado por novos feitiços", apaixonou-se por segunda mulher. Descoberto o caso, escreveu à primeira mulher, conseguiu ser desculpado e voltou a habitar o pátio do Penalva na Calçada do Duque. Não rompeu, contudo, com a amante, dissimulando com ambas. Até que, num domingo, ele fez uma festa no pátio, "congregara mais vizinhos do que neles cabiam, havia balancé de cavaquinho e flauta, e petisco de fígado e salada". A primeira amante, imaginando que ele era só dela, fazia as honras da casa e, ao perceber que acabara o vinho, preparara-se para ir buscar mais. Uma das mulheres presentes prontificou-se a ir em seu lugar. Como o ar da noite estava frio, a dona da casa emprestou-lhe seu xale. Ao sair do pátio, foi confundida como mulher do judeu, porque tinha o "rosto meio embuçado" e estava escuro. Ela foi atacada pela amante, que "[a] tomou de improviso, vergou-a para baixo de si, meteu-lhe a cabeça entre os seus joelhos, levantou-lhe as roupas, sacou de um tamanco e principiou a açoita-la com toda a fúria que os zelos podem dar a quem anda de tamancos" (RUL, IV, n. 32, 27 fev. 1845, p. 390). Em pouco tempo era uma briga entre todos os participantes da festa mais a amante e seu irmão. Foram todos parar à polícia. Mas, "pela manhã no juízo de polícia correcional não houve nenhum queixoso" e foram "para a taberna todos selar as pazes Todos? - não. Dois faltavam aí. O hebreu e a vingativa, que desapareceram ambos juntos" (RUL, IV, n. 32, 27 fev. 1845 , p. 390). 
Apesar da crítica a esse tipo de ambiente, Castilho parece se divertir ao narrar com algum humor os detalhes desse bas-fond quase naturalista a que não faltou descrição da indumentária, do que se comia, do tipo de divertimento e das brigas. O cronista aponta o modo como essa população que vivia à margem se autoprotegia do poder constituído. Aí estaria o perigo, nessa vida fechada e secreta de pátios capaz de evitar a correção. Tanto que esses espaços "encantados e quase incógnitos à própria polícia" eram deplorados em outra crônica sobre a urbanização de Lisboa. Nesses lugares "enxameava [...] tudo o que a sociedade tem de fezes - a prostituição, a embriaguez, o roubo, a nudez e a fome; a mocidade caduca, a infância sem alegria, a velhice sem veneração" (RUL, II, n. 7, 03 nov. 1842, p. 81). Essa destruição do "Pátio do Patriarca às abas da Misericórdia" foi aplaudida pelo jornalista. Porém, nem todo "bota abaixo" era sem censura. Castilho não desculpou a Câmara de Lisboa nem Caldas Aulete, que comprara a área, pela destruição de uma torre de defesa de d. Fernando para a abertura da Rua Nova da Trindade:

Despovoada de portugueses, desguarnecida do seu capacete de ameias, resistiu do único modo que pôde; com a sua mesma dureza: fez voar em pedaços muito alvião sacrílego, muita picareta filosófica, muita marreta de niveladores. Ao cabo não teve remédio senão ceder, e quatro séculos puseram no pó a sua fronte espedaçada! E aos pés descalços dos agentes da filosofia passaram com indiferença por cima dessa destruída múmia de uma glória nacional - que importava? não nos ficavam vivas tantas modernas! (RUL, II, n. 7, 03 nov. 1842, p. 81).

Há, portanto, diferença clara para ele entre o que poderia ser destruído para que algo novo fosse criado e o que deveria ter ficado de pé. Os pátios populares não eram, segundo Castilho, lugares próprios à civilização. Por outro lado, à torre medieval não associava ele a literatura ultrarromântica que desprezava. Não é, entendamos, o tema ou o ambiente da literatura - ou da sociedade, agora especificamente - que importava, mas o uso que se faz dela. A torre de Álvaro Pais não era prejudicial ou inútil. Era um monumento da glória nacional e, como tal, poderia servir de exemplo ou incentivo às novas gerações. Em seu lugar, ironicamente, ficava "a glória de abrir uma pobre e supérflua rua".

Supérfluo, excessivo, exagerado - é assim que António Feliciano de Castilho via muitos dos casos da "moderna" Lisboa. Como poeta, a preocupação com a forma continha a imaginação desregrada. Como jornalista, esteve atento aos perigos das exacerbações e buscou caminhos para a ordem e manutenção da paz. Vivia-se, ao que parece, uma epidemia de sentimentalismo e desesperação que era preciso conter. Suas causas? Pobreza, licenciosidade e romantismo!

Sim, romantismo. Muito antes de Eça de Queirós acusar a sociedade portuguesa de romântica n'Os Maias, Castilho o fazia nas folhas da Revista Universal Lisbonense. Há uma longa série de notícias com títulos sarcásticos contra o "romantismo" cotidiano. "Já chegou o romantismo a Alfama" (RUL, I, n. 31, 05 maio 1842, p.374) conta o caso de um homem que foi preso enquanto espancava a própria mãe. No "Romantismo da Vida Real", (RUL, III, n. 27, p. 331-332, 22 fev. 1844), extrai-se outra história do Periódico dos Pobres do Porto, contando o caso de um homem que, apaixonado por nova mulher, resolve envenenar sua esposa hospitalizada enviando-lhe bolos de maçã com arsênico. O "Mais Romântico", extraído também dos Pobres do Porto (RUL, I, n. 35, 02 jun. 1842, p.419), narra o de um primo que envenenou o outro com arsênico misturado ao vinho; para, no "Menos Romântico" (RUL, I, n. 38, 23 jun. 1842, p. 455), retificar a história: afinal o homem tinha morrido de doença. $\mathrm{O}$ natural não seria romântico, portanto. Diferentemente dos suicídios. No "Romantismo Sapateiral" (RUL, I, n. 47,08 set. 1842 , p. 557), um sapateiro foi encontrado enforcado junto à cama, "não se pode atinar qual fosse a causa dum facto tão desesperado". Exemplos não faltavam. Um curtidor suicidou-se, era "O Romântico Democratizado" (RUL, II, n. 40, 22 jun. 1843, p. 503). Outro que tentou suicídio e não conseguiu, "Ainda mais um Romântico à Ridícula" (RUL, II, n. 40, 22 jun. 1843, p. 503-504). Em Lisboa, o local preferido pelos suicidas era o aqueduto das águas livres.

Em "Os Arcos das Águas-Livres" há um relato dos suicídios a partir daquele aqueduto. A menina Rosa era espancada pela mãe, até que um dia se cansou e resolveu se jogar dos arcos. Um homem percebeu o intento e a impediu. Entretanto, na mesma semana, um "infeliz mancebo" se jogou do mesmo ponto. A solução Castilho propõe sarcasticamente:

Havíamos pedido à policia, por tudo quanto há de santo e venerável no mundo, e fora dele, uma e muitas vezes lhe havíamos pedido e obsecrado - que defendesse com guardas o ingresso daquela ponte da morte a todo o caminhante desacompanhado. - Devia de ser insensato o nosso requerimento, pois que nunca obteve despacho. - Convertê-lo-emos hoje em outro, que porventura logrará melhor fortuna. Tem mostrado a experiência, que essa mesma pequena dificuldade de subir ao parapeito para dar o salto, tem salvado (como desta vez) a alguns outros desesperados. - Mandese rasgar nesse parapeito uma boa portada sempre aberta para a profundez do vale; escrevam-se-lhe por cima com grandes letras bem doiradas - FÁCIL E GRATUITA SAIIDA DO MUNDO PARA QUEM QUISER; - o cemitério não fica longe; puxem-no 
até aos pés do soberbo monumento: abram nele uma grande cova bem por baixo do despenhadeiro para poupar escusados trabalhos quotidianos aos enterradores, que sentados nos degraus de algum tumulo ou encostados às suas enxadas, gozarão do novo e romântico espetáculo de ver chegar vivos e sãos e por seu pé ao cemitério, os que um momento depois hão-de enterrar.

Pediríamos também - se ousássemos pedir ainda mais - que a esse vale dos suicidas se desse algum título que melhor convidasse a imaginação - o vale do repouso, as delícias ou outro semelhante; que o abismo se plantasse de verdura e flores para melhor cativar os olhos - e que finalmente lá em cima houvesse de dia e de noite quem acudisse aos irresolutos com o decisivo copo de bebida espirituosa (RUL, II, n. 3, 05 out. 1842, p. 35-36).

Talvez assim, ou a Câmara de Lisboa fizesse alguma coisa ou os suicídios, "romântico espetáculo", ali diminuiriam pelo ridículo em que foram transformados pelas crônicas de Castilho.

O redator também criticava os excessos por amor, que acabavam levando a ações desesperadas e violentas. É o caso de algumas notícias sobre relacionamentos amorosos conturbados. São situações causadas por ciúmes ou pela impossibilidade de realização amorosa. Em "Amores Trágicos" (RUL, II, n. 42, 06 jul. 1843, p. 526), Castilho começa por descrever a festa de S. João em Lisboa: "a Praça da Figueira estava cheia de luzes, de palmitos, de capelas, de ramalhetes, de letreiros amorosos, de vestidos de chita novos, cordões e arrecadas de oiro nas colarejas, no terreiro danças e descantes ao som de violas flautas e ferrinhos", para depois destacar suas personagens. Uma queijadeira, "bela por moça, bela por bela, e bela até por festejada" que era alvo de olhos cobiçosos. "Mais de um gastrónomo comeu das suas queijadas sem lhes tomar o gosto, mais de uma distraída mão, recebendo ou pagando a sua mercadoria, pôde dar testemunho do macio e acetinado de seus dedos". Em meio a esses episódios, "dois personagens avultam aí, permanentes na primeira luz do quadro" ao pé do tabuleiro das queijadas. "Ambos amantes e ambos amados, se em mostras nos podemos fiar; mas um amado no pretérito, o outro no presente: do futuro nem ela mesma se atreveria a afirmar coisa alguma". É então, causada por essa inconstância amorosa da queijadeira que a ação se desenrola. A moça apenas tinha sorrisos para o amado do presente, "seu sátiro", enquanto ao outro "lançava de longe em longe um volver de olhos, semelhante... semelhante a quem, depois de ter dado o miolo de uma queijada a outrem vos atirasse com as cascas!", conta Castilho apropriandose metaforicamente da profissão de sua personagem. O amante desprezado era "um valentão", mas sem forças para aguentar situações dessas "puxa secretamente por um ferro: antes que alguém haja podido impedir-lhe ou adivinhar-lhe a ação, mergulha-o inteiro no coração ébrio de felicidade, e desapareceu" ( $R U L$, II, n. 42, 06 jul. 1843, p. 526).

Esse homicídio, "realçado pelo aparato festivo do sítio", demonstra como a felicidade pode se transformar em tragédia se alguém se deixa levar pelos sentimentos. Não é este o tema de fundo d'A Noite do Castelo, do próprio Castilho, a vingança por ciúmes em meio a uma festa? Ficcional ou não, cantado numa idade média fantasiosa ou narrado na Lisboa liberal, o crime passional estava presente no imaginário daquela sociedade.

É então, ainda sobre o mesmo tema, que Castilho conta caso semelhante, mas explorando o conteúdo exótico, em "Ciúmes Negros" (RUL, II, n. 44, 20 jul. 1843, p. 552). Afinal, segundo ele, "a veemência do amor preto é proverbial - os seus ciúmes devem ser excessivos: - são-no: há disso provas inegáveis; bastava o negro de Veneza". Provavelmente o "pai Francisco" não conhecia Otelo quando deixou enciumada "Mãe-Rosa", casal que vivia "em um casebre para as partes da Lapa". "Mãe-Rosa [...] já tinha mais de uma vez substituído aos monólogos, suspirados e chorados sem testemunhas, as cenas violentas de queixas, de exprobrações, até de ameaças". Até que uma noite, cansada de esperar sozinha, imaginou uma vingança. Quando o "seu desertor por amor" (grifos do autor) chegou e bateu a porta, ela "abriu, dissimulou - deitaram-se". O marido logo adormeceu enquanto "só velavam no aposento a candeia de folha, mal desperta, o registo da Senhora do Rosário e a esposa, sentada na cama e com os olhos acesos cravados no seu ofensor". Castilho interrompe a narração para se dirigir ao leitor: "esta cena muda deveu ser longa; que a fantasie quem tiver o talento dramático; nós limitamo-nos em historiar". Ora, estava ele apenas narrando um fato? O cronista acabara de contar em detalhes a chegada do marido, a idealização da vingança por parte da mulher ciumenta e descrito o ambiente noturno daquele pobre casebre a ponto de o leitor quase ver no escuro os olhos acesos de raiva de Mãe-Rosa. Haveria ali uma crítica a muitos "talentos dramáticos" de sua época? A crônica avança:

saltou para o chão mãe-Rosa, terrivelmente sublime na expressão negra do negro rosto, trágica na atitude como uma estátua nua de ébano, representando a vingança, e mostrando, através do seu sorriso de triunfo, duas falanges de dentes de marfim. Irá cravar-lhe um ferro no coração? Como Otelo, que afoga com o travesseiro a sua adorada Desdémona adormecida, irá sufocar o desprezador dos seus encantos? - Não: não é a vida, que ela pretende arrancar-lhe. A faca da sua mesa, que tantas vezes cortou o pão entre ambos, não derramará aquele sangue; o travesseiro, onde tantas vezes 
comungaram sonos pacíficos, conversações amorosas, penas, prazeres e esperanças não fará emudecer para sempre àquele, que ela não detesta senão porque o ama. Africana e silvestre na sua cólera, é com os dentes como tigre, que ela se arremessa de um pulo sobre a sua preza. Quando o infeliz acordou com um grito frenético não era homem (RUL, II, n. 44, 20 jul. 1843, p. 552).

O fato, tão bárbaro, fez com que Castilho transformasse a negra Rosa em animal silvestre e africano, o tigre que salta sobre a presa. É interessante observar como o narrador prolonga o quadro refletindo sobre possibilidades de ação - talvez mais comuns e mais facilmente previstas pelos leitores da Revista - antes de apresentar a cena final em que a mulher castra o homem com os dentes. Ironicamente, o redator comenta que, se voltarem a se reunir, viverão uma "vida pacífica e isenta de ciúmes".

Agir assim não era bem visto por António Feliciano, que várias outras vezes contou o desfecho trágico desse tipo de situação. Qual seria então o limite dessa loucura de amar? Afinal, em alguns momentos o amor não é visto por seu lado ridículo, mas por seu tom trágico e triste. É o que acontece, por exemplo, em "Nova Moema". Nessa história, "um caso triste, que bem merece conservado em memória" (RUL, IV, n. 3, 08 ago. 1844, p. 30), conta-se que uma moça de dezoito anos, "saloia, e galantinha" andava de amores por um dos condenados ao degredo, conversando com ele à grade da prisão. Chegou o dia da partida, a menina estava presente e "só então acreditou na possibilidade de uma desgraça, que aliás sabia inevitável" ( $R U L$, IV, n. 3, 08 ago. 1844, p. 31). A narração é nesse ponto interrompida para uma breve digressão:

Quantas dores assim obscuras e caladas não vão pelo fundo da vida real, iguais e superiores às fantasiadas pelos escrevedores noveleiros! - não só cada cidade tem os seus mistérios como os sonhou em Paris Eugenio Sue, se não que os tem cada aldeia, cada casa, cada indivíduo e até os que mais felizes se reputam!!! (RUL, IV, n. 3, 08 ago. 1844, p. 31 - grifo do original).

A pequena saloia seguiu o bando de cativos até o cais do Sodré, viu seu amado embarcar e o barco a afastar-se, e atira-se no rio. A jovem foi retirada das águas enquanto as pessoas gritavam "está doida! está doida", ao que ela respondeu "chamam doidice à desgraça que se não pode sofrer!". Sua dor parece ter consternado Castilho. Em vez do sarcasmo ou da ironia de outros textos, percebese um entendimento da parte do narrador, vendo nela a dor superior à ficcional, a que vai "pelo fundo da vida real", apesar de reconhecidamente semelhante à da personagem de Santa Rita Durão. Seria este um "amor de perdição" como o de Mariana que se joga às águas para morrer junto a Simão? Se Portugal vivia uma epidemia ultrarromântica, como vemos Castilho acusar repetidamente, alguns amores são mais fortes do que o apresentado pelas novelas e pelos dramas.

Contudo, não nos enganemos. António Feliciano não defende que o amor é superior a tudo. Ele revela em suas crônicas um pragmatismo atento à realidade que desmente qualquer apoio ao sentimentalismo exacerbado, como na situação apresentada pela presença grotesca de gigantes em Lisboa.

Quem duvidasse da existência dos gigantes e pigmeus, descritos por Gulliver nas suas mui verídicas viagens, não teria mais para se convencer do que dirigir-se à rua Larga de S. Roque, junto à igreja do Loreto, procurar a casa, que na taboleta lhe mostrar gigantes e anões, pagar 120 ou 200 réis, segundo quiser estar sentado ou em pé, e entrar: - diria que é o próprio Gulliver, que veio para ali estabelecer-se, - trazendo vivas e palpáveis algumas amostras daquelas extraordinárias gentes, que visitou. Enganar-se-ia. Tudo aquilo vem de França. Não admira; tudo o que temos de maior e de mais pequenino, de lá nos vem há muito tempo ( $R U L$, III, n. 21, 11 jan. 1844, p. 256-257).

Nessa crônica recheada de referências literárias, incluindo Swift, Virgílio, Ovídio e Camões, e a pintores como Vernet, Delaroche e Lafont, o tom cômico de crítica ao gosto pelo insólito é constante. Sem falar na própria reação à importação de moda, costumes e literatura francesa. Afinal, é comum nesses textos de Castilho aproveitar um tema para falar de outros. Tudo isso desencadeado pela presença da gigante Mademoiselle Camilla e da anã Madama Alphonse. O caso fica mais intrigante quando aparece em Lisboa D. Joaquim Eleizegui, "chegado fresquinho, o melhor disséramos frescão, de Guipuzcoa", no texto "Gigante" (RUL, III, n. 42, 05 jun. 1844, p. 509). O redator logo imagina que os dois gigantes apresentam as condições para o casamento e que fora uma sorte os dois estarem ao mesmo tempo naquela cidade. Parece que propuseram ao "gigante" que "pedisse a manápula de Mademoiselle Camilla, por não perder uma ocasião de se casar".

Objetaram-lhe com o sabido.

Qual será o amor bastante...

mas ele solveu a dúvida declarando, que havia na sua terra moças de corpulência proporcionada à sua. Se não é fanfarrice castelhana, bem-aventurados os fabricantes e mercadores de panos de tal país, que de certo não têm mãos a medir" (RUL, III, n. 43, 13 jun. 1844, p. 522).

O redator trata o caso com o mesmo tom grotesco com que os gigantes se apresentam, sugerindo não o pedido da mão, mas da "manápula". A visão prática da vida não é 
obscurecida pela recusa do Adamastor ${ }^{3}$ espanhol. Mesmo ironizando, António Feliciano demonstra estar atento a questões de mercado, de oferta e de demanda. É refletindo sobre os reais motivos para tanta violência e desesperação em Portugal, que Castilho mais se aproxima das questões sociais. Assim é que, mais uma vez pelo caminho da ironia, o redator apresenta reflexões sobre seu tempo:

\begin{abstract}
Um pobre trabalhador, assistente em Alcântara, recolhia cansado das fadigas diurnas para a sua humilde habitação, saboreando-se já em espírito no só por só da sua ceiazinha frugal entre a lareira e a enxerga com sua mulher moça e amável. Sua mulher é toda a sua família; todo o ornamento e luxo da sua vivenda, toda a sua fortuna, o alfa e o ômega de todos os seus desejos; filhos não os tem nem, por ora, a mais leve esperança deles. Cifra nela só o amor, que havia de repartir pelos herdeiros da sua penúria: o afeto assim simplificado é uma grande economia: não há, para os tempos de décimas industriais, como aquilo de ser proletário sem prole (RUL, II, n. 22, 16 fev. 1843, p. 280).
\end{abstract}

Afinal, é contra um mundo que transforma tudo em mercadoria, que apreça os valores e os sentimentos, que os românticos se insurgiam, como indicam Michael Löwy e Robert Sayre. ${ }^{4}$ Para mostrar as penúrias de viver nesse mundo de barões, para lembrar Garrett, Castilho alia à vida e aos amores do pobre proletário o vocabulário dos negócios, com suas cifras, economias, décimas, etc., que não caberiam de fato ao trabalhador. Esse assistente acaba por não concordar inteiramente com a máxima de que é melhor "ser proletário sem prole". Não é mera dificuldade etimológica. Sabe-se que proletário tem justamente este nome por não ter, segundo o exame de Marx, nada mais a oferecer à sociedade do que sua força de trabalho e sua prole para reproduzir as relações capitalistas de produção, reempregando o termo utilizado pelos romanos para designar aqueles que não tinham propriedade alguma e cuja única utilidade para o Estado era gerar proles, filhos, para engrossar o exército. A dificuldade, no caso, é que o trabalhador chegou um dia em casa e encontrou um bebê no colo da mulher. "O amor paterno é muitas vezes tão fraco financeiro, como muitos dos financeiros mais acreditados". O homem fica feliz com "aquela cifrazinha animada de toda a sua ternura" e sai espalhando pela vizinhança que era pai. Ora, até aqui não há nada de

\footnotetext{
3 No Canto V d'Os Lusíadas, há o episódio do gigante Adamastor com a fala da deusa: "Qual será o amor bastante/ De Ninfa, que sustente o dum Gigante?" (Lus., V, 53, vv. 7-8).

4 "Antes de mais, indiquemos com duas palavras a essência de nossa concepção: para nós, o romantismo representa uma crítica da modernidade, isto é, da civilização capitalista moderna, em nome de valores e ideais do passado (pré-capitalista, pré-moderno). Podemos dizer que, desde sua origem, o romantismo é iluminado pela dupla luz da estrela da revolta e do 'sol negro da melancolia' (Nerval)" (LÖWY \& SAYRE, 1995, p. 34 - grifos dos autores).
}

espantoso para figurar como fait divers nas folhas da Revista. Todavia, ao terceiro dia, a polícia bateu à porta dessa família para que devolvessem a criança. A verdadeira mãe era uma mulher que morava perto das pedreiras onde trabalhava a esposa do proletário e que havia pedido a ela que colocasse na roda a criança. "Sabedora da fraude, a das pedreiras, e tão dura e tão bruta como elas, recorreu à autoridade do cabo para reaver a sua propriedade, e fazer dela o uso que lhe aprouvesse" (RUL, II, n. 22, 16 fev. 1843, p. 280). É uma série de brutalidades cuja comparação só poderia ser mesmo feita com a pedreira: abandonar o recém-nascido, arrancá-lo da família que o acolheu, e a própria pobreza em que todos esses personagens vivem.

São vários os relatos de vidas marcadas por dificuldades financeiras. Histórias que a redação da Revista sabe serem pequenas amostras de um problema maior, que se alastra pelo país inteiro. No mesmo ano, perguntaria Almeida Garrett nas Viagens "se já calcularam o número de indivíduos que é forçoso condenar à miséria, ao trabalho desproporcionado, à desmoralização, à infâmia, à ignorância crapulosa, à desgraça invencível, à penúria absoluta, para produzir um rico? [...] cada homem rico, abastado, custa centos de infelizes, de miseráveis" (RUL, III, n. 4, 14 set. 1843, p.43-44). Castilho imaginara também um número. Uma joia de um rico salvaria duzentos velhos, duzentas donzelas e duzentas crianças, "centos de infelizes, de miseráveis". Numa sociedade que teimava em reduzir tudo a cifras, como diria Garrett no mesmo terceiro capítulo, o redator alertava:

A praga do latrocínio vai crescendo: é evidente que já a corda do algoz, ainda que mais diligente andasse, não bastaria.

Estes males sociais não se curam tanto pelo decote das ramas viciadas, como pelos remédios aplicados à raiz. Enquanto se aumentarem os tributos, que matam o trabalho, em vez de se aumentar o trabalho, que suaviza os costumes: enquanto se fizerem monumentos em lugar de escolas de rudimentos literários e religiosos, a classe dos carrascos há-de ser a mais ativa de todo o Estado (RUL, II, n. 22, 16 fev. 1843, p. 277).

Todavia, para algumas violências, o cronista ainda defende punição exemplar, como no texto "Argumentos vivos a favor da pena capital (artigo que só homens deverão ler)". A crônica narra uma longa sequência de crimes hediondos incutidos a uma "quadrilha de malfeitores" julgados pelo tribunal de Moimenta da Beira. O grupo roubava, matava, torturava, ameaçava, estuprava, espancava, arrancava membros e impedia o acesso de suas vítimas a sacramentos. São ações tão brutais que, ao recolher algumas crônicas, Júlio de Castilho sentiu necessidade de censurar algumas partes, como aponta 
Ernesto Rodrigues, que selecionou esse texto para o seu livro Crónica Jornalística. Século XIX (2004).

Foram censurados, além de uma comparação entre o líder do bando e d. Miguel, alguns dos sucessos perpetrados por Nuno da Silva e Domingos Tomé, que incluem o estupro individual da "velha Perpétua" e sua filha, invasão de sua casa, onde os dois criminosos se fizeram alimentados, além de bestialismo ${ }^{5}$ com uma cabra e promessa de incesto. Castilho conclui com aviso contra malfeitores assim: "há ainda na terra justiça; há na sociedade o instinto da conservação; e por cima de tudo isto, lá no alto, uma Providência" ( $R U L, \mathrm{I}, \mathrm{n} .48,15$ set. 1842, p. 571).

O papel da Revista era civilizar. Para isso, não bastava ilustrar, educar, seus leitores. Era preciso lutar contra os que apenas tinham "interesses materiais" e também contra hábitos do Portugal velho que não morreram com a vitória liberal. Castilho espanta-se ainda no primeiro tomo ao perceber um povo bárbaro, enquanto narra "Os três últimos dias de um sentenciado" condenado à pena de morte:

É porque dentro, e misturado com cada povo, anda outro povo, que não é, nem pode ser liberal; que não é, nem sabe ser cristão; que não é, nem aspira a ser gente: - diferem dos selvagens em trajarem à europeia. - E que outro nome quereis que demos, por exemplo, a quem, porque no largo do patíbulo e à hora da execução um dos espectadores cai de cima da meda de pinho, onde trepara para ver, levanta, e repete gargalhadas estrondosas? - E isso foi também neste mesmo memorável sábado 17 do corrente Abril. - Selvagens à europeia, lhes chamamos, relevem-nos o termo; foi mal, - tamanha injúria não a mereciam os pobres selvagens! (RUL, I, n. 29, 21 abr. 1842, p. 351).

Esta notícia, publicada com assinatura de António Feliciano de Castilho - o que poucas vezes acontece -, apresenta algumas diferenças em relação às demais que temos apresentado neste capítulo. Além de ser uma das maiores, talvez pelo excesso de detalhes desses três últimos dias de vida de Francisco de Mattos Lobo, apresenta diversas notas de rodapé com digressões e comentários sobre o que era narrado. A reflexão mais viva é a que motiva todo o relato. Mattos Lobo fora julgado e condenado pela morte de várias pessoas de uma

\footnotetext{
"Tornados os ausentes com o vinho e fechada a porta (quem o crerá!) não cevada ainda a bestial sensualidade dos dois infames, concebem e executam, à vista de ambas as suas prostituídas, uma nova afronta contra elas, contra a natureza, e contra si mesmos; um deleite, que santifica, se é possível, os dois crimes que acabam de perpetrar [o estupro individual de cada uma, mãe e filha]! não o diremos, não o podemos dizer! A cabra, destinada à ceia, estava ainda viva.!.!.! e eles, eles mesmos, ousaram depois banquetear-se com suas carnes, e obrigar as duas assombradas a comer delas! e depois ainda, recomeçar, ambos, com a pobre moça o mesmo abominoso passatempo" (RUL, I, n. 48, 15 set. 1842, p. 571).
}

mesma casa. A pena foi a morte no patíbulo, obrigando a procissão da cadeia à praça de execução que passasse em frente ao imóvel onde os crimes foram cometidos. Deveria Portugal manter a pena de morte em pleno regime liberal? Vimos acima que Castilho apontou uma série de crimes bárbaros como argumentos a favor de sua manutenção. É, no entanto, ao descrever a morte de Lobo cujo "suplício [,] coisa horrenda! durou mais de um quarto de hora" (RUL, I, n. 29, 21 abr. 1842, p. 351), que ele justifica seu ponto de vista:

Se cumpre ou não abolir a pena de morte, ponto é sumamente controverso. As nações mais adiantadas ainda não chegaram a resolvê-lo, que nós tão faltos da instrução popular, que civiliza e moraliza, e tão distantes ainda da possibilidade de um sistema penitenciário, quiséssemos destruir para já este castigo, seria a mais grave, a mais perigosa de todas as imprudências. Se tais utopias se fizessem realidade não tardariam em morrer elas próprias sob o punhal dos assassinos. Que temos pois que fazer quanto à pena de morte? O mesmo que há já muito, ensinou a França, o que provavelmente a Inglaterra, que ainda também enforca, não tardará a adotar. - Substituir o ferro à corda, o momento ao quarto de hora, e a máquina ao braço humano (RUL, I, n. 29, 21 abr. 1842, p. 351).

António Feliciano não estava mesmo satisfeito com o estado atual da pena capital em Portugal. A própria execução ficou próxima do ridículo por o carrasco se enroscar na mesma corda do enforcamento e ficar dependurado pelo pé enquanto a corda tentava estrangular o condenado, que sofreu por quinze minutos por o fechamento do nó mortal ter sido atrapalhado. Além disso, num dia grave como o que a sociedade mata um de seus membros para castigá-lo por seus crimes, seria preciso reflexão sobre a justiça, pensava Castilho, o que não existiria se a cidade, em vez de ficar de luto, permitia festas e comédias públicas nesse dia.

A pena capital estava em discussão naquele tempo e sua abolição era uma luta dos liberais. As últimas execuções foram na década de 1840 . Usar casos como esses para justificar a pena de morte é uma posição reacionária de Castilho que, em meio à violência da época, temia o fim desse tipo de punição. A solução para ele, naquele momento, era alterar sua aplicação e suscitar a discussão do tema.

Num país com sistema penitenciário deficiente, sem instrução popular, "que civiliza e moraliza", cabia também à imprensa auxiliar nesse trabalho levando conhecimento. Por isso a Revista atacava não apenas a violência que ululava, também exercia uma dupla ação contra as superstições. Por um lado, criticava-as fortemente. A sequência de artigos contra "mulheres de virtude", cumpria o dever de "ir sacando constantemente 
à luz quantos destes casos de ruins superstições nos chegam ao conhecimento, para espertar, nos que têm o direito e a força, a vontade e a resolução de lhes dar mate; e havemos de perseverar" ( $R U L$, IV, n. 6, 29 ago. 1844, p. 71). Por outro, desmentia diversos casos aparentemente insólitos que eram divulgados pela cidade, todavia, isso não o impedia de noticiá-los, deixando para o final o desvelo do que causa estranhamento, quando não lida com o assunto apenas ironicamente sem apontar saída real. Nem poderia impedi-lo. Afinal, não podemos nos esquecer do que diz Barthes: "o espanto implica sempre uma perturbação, já que em nossa civilização todo alhures da causa parece situar-se mais ou menos declaradamente à margem da natureza, ou pelo menos do natural" (1970, p.61). Não haveria fait divers sem perturbação.

Perguntamos, então, se esse espanto do escrever seria capaz de transformar esses textos de fait divers em algo diferente. Para já, o melhor seria afirmarmos que todos os artigos da Revista Universal Lisbonense aqui selecionados e analisados fazem parte da seção "Notícias". Apesar disso, diferenciam-se das informações políticas, econômicas, meteorológicas, de guerras, etc. arroladas sob a mesma rubrica. A diferença é que "no nível da leitura, tudo é dado num fait divers; suas circunstâncias, suas causas, seu passado, seu desenlace; sem duração e sem contexto êle constitui um ser imediato, total, que não remete, pelo menos formalmente, a nada de implícito" (BARTHES, 1970, p.59). Enquanto isso, a informação implica um conhecimento prévio; ela possui uma duração. Contudo, observamos nesses textos de Castilho uma forma que faz com que esses escritos extrapolem a ideia de notícia pura, mesmo tendo em mente o alerta de Barthes de que "que o fait divers é literatura, mesmo se essa literatura for considerada má" (idem, p. 67).

Como temos vindo apontando, essas histórias costumam, além do uso quase constante do humor irônico, ser construídas fazendo uso de três artifícios: intertextualidade explícita ou implícita com a literatura e outras artes; abertura a um conhecimento prévio de outros assuntos não diretamente relacionados e desnecessários para sua compreensão, por servirem de reforço ou lembrança a outros tópicos abordados pela revista; narratividade que se aproxima do ficcional (estratégias de suspensão, metáforas, abertura semântica, digressões, etc.). Deste modo, Castilho transforma as notícias, que deveriam ser textos objetivos, explícitos e fechados em si mesmos, abrindo-as a uma articulação com o resto da Revista Universal e com seu programa.

Assim, ao lermos essa produção castilhiana, somos levados àqueles lugares e àquele tempo pelas mãos do narrador, que nos faz, inclusive, penetrar na mente de suas personagens, mesmo tendo sido elas pessoas reais. É sensação semelhante à que tem Jorge Fernandes da Silveira quando comenta as crônicas de Fernão Lopes: "Convidando o leitor a ver ('agora, olhai como se estivésseis presentes'), o narrador suspende o relato, e, como se se calasse, passa a ver-se na narração, transformando-se ele também em instância da narrativa e em efeito de leitura" (SILVEIRA, 1992, p. 34). Isso porque, na crônica, "esse modo de ver-se com o outro cria um sentido do tempo para a subjetividade e as suas relações com o tempo histórico" (SILVEIRA, 1992, p. 36). E nota-se em muitos desses artigos de Castilho a mesma relação com o tempo e "o narrador que, reflexivo assiste $o$ fato e o narrador-outros ele próprio que, comovido, assiste ao fato" (SILVEIRA, 1992, p. 33 - grifos do autor). Caso exemplar é o próprio relato "Os três últimos dias de um sentenciado", no qual o cronista instiga o leitor a acompanhá-lo e a ver como ele - "imaginai (se não vos falta o ânimo) tudo isto" ( $R U L, \mathrm{I}, \mathrm{n} .29,21 \mathrm{abr}$. 1842 , p. 347), ao mesmo tempo em que ele é mais um na multidão acompanhando a procissão ao patíbulo.

Todavia, esses textos não são realmente crônicas stricto sensu, uma vez que estão deslocadas fisicamente de seu local habitual. Acompanhando a produção jornalística brasileira do século XIX, Marlyse Meyer (1992) identifica que os folhetins (não ainda o romance-folhetim, mas toda a diversidade de escritos que iriam ocupar o espaço do feuilleton, o rez-de-chaussée do jornal) começaram sua carreira sob a rubrica Variedades, onde é possível "ir ao encalço das primeiras manifestações da ficção, como de um espaço livre à criação e à transformação do jornal" (1992, p. 105). Enquanto isso, esses textos de Castilho não aparecem na seção "Variedades" da Revista Universal Lisbonense, mas no noticiário. Tal localização no espaço do jornal não impediu, contudo, Ernesto Rodrigues de, tal como vimos, identificar uma delas como "crónicajornalística".

Causa mesmo espanto António Feliciano de Castilho não ter sido apontado ainda como cronista, ou, seguindo um vocabulário mais próprio da época dessas produções, como folhetinista. A crônica "é a amiga da verdade e da poesia nas suas formas mais diretas e também nas suas formas mais fantásticas - sobretudo porque quase sempre utiliza o humor" (CANDIDO, 1992, p. 14). E Castilho, jornalista-poeta, defendendo o que há de verdade e de ficcional tanto no jornal quanto em poesia, estabelece uma ponte em dois sentidos entre o jornalismo e a literatura. Esses textos do noticiário da $R U L$ são breves contos "de atualidade", atentos à vida portuguesa, numa linguagem mais leve e irônica do que seria esperado de um "árcadepóstumo", colocando-os como um dos pontos de partida tanto do romance de atualidade quanto do folhetim, podendo ombrear-se, nesse aspecto, com António Pedro Lopes de Mendonça e Júlio Cesar Machado, que 
começaram depois dele. Este folhetinista descreve bem o que temos defendido:

não sei se a musa que favorece o berço dos poetas lhe havia concedido largamente a invenção; não sei também se as suas traduções de Moliére foram impecáveis: mas em todo o caso, dizer que Castilho sabia a sua língua e foi excelente tradutor como centos de vezes se tem dito para não dizer mais nada, não basta: em todas as suas obras sente-se um moralista e um poeta, revelando-se em conceitos de uma gravidade penetrante, profunda, própria de uma alma apaixonada e verdadeiramente humana! (MACHADO, s.d., p. 149).

Talvez, como se indaga Machado, Castilho não tenha recebido da musa "largamente a invenção". Isso não o impedia de criar. Ou melhor, seu método ficcional era diferente dos demais. Como poeta cego, ele era capaz de criar textos ecfrásticos a partir da descrição de um quadro contada a ele por outrem, como faz a partir de um quadro pintado ou litografado, como o "S. Bruno" de Sequeira ou o "D. Maria II" de Sendim, encetar uma narrativa. Ele próprio conta num dos paratextos do Ciúmes do Bardo como ele e o irmão se divertiam sorteando temas e palavras para comporem poemas, valorizando a criação que parte de algo dado previamente, como nesses casos, em vez de depositar toda a composição artística na invenção que parta da subjetividade ou de algo abstrato. Castilho, ao receber as notícias por cartas ou por ouvi-las contar, era capaz de transformá-las também, como se fossem pinturas cuja descrição ouvira antes de elaborar essas narrativas. Se essas crônicas não podem ser rotuladas explicitamente de ficção, uma vez que sua origem estava em fatos jornalísticos, elas não são isentas de criação artística.

No sentido contrário, o cotidiano que António Feliciano descrevia na Revista Universal formava um novo manancial de temas, metáforas e vocabulário para suas outras atividades. É o que se pode perceber a partir do relato do que surgia "nesse século tão criador" e da capacidade castilhiana de compor enredos a partir de imagens que fisicamente não enxergava, mas que lhe eram relatadas.

Em 1844/1845 um daguerreotipista francês estabeleceu-se em Lisboa. Edouard Thiesson, que chegou a retratar o próprio Daguerre, montou na Rua dos Mártires um estúdio fotográfico comercial. Castilho conta uma visita a esse estabelecimento em "Luz Pintora" ( $R U L$, IV, n. 27, 23 jan. 1845, p. 329-330). Num diálogo entre dois amigos, um dos quais querendo um retrato seu para entregar à mulher amada, ficamos conhecendo o estúdio, a descrição de algumas fotografias ali em exibição, o cenário montado, a posição em que o fotógrafo colocava seus clientes imóveis, as dificuldades referidas por Thiesson e o próprio ato de fotografar:

puxou do relógio, mostrou a hora, minuto e segundo em que se estava, e chegando a um cofrezinho, colocado, quatro ou cinco pés diante da cadeira, levantou uma corrediça que o fechava pela frente, e pôs-se a considerar alternativamente o movimento das nuvens e o do ponteiro; apenas este marcara o seu décimo quinto passo, fechando a súbitas o cofre exclamou;

- Já vos tenho em meu poder.

E desapareceu com a enigmática boceta. Quinze minutos depois de operações misteriosas, em quarto escuro, fechado e sem testemunhas, Mr. Thiesson voltou trazendo na mão o mais cabal e irrepreensível de todos os retratos: um verdadeiro espelho com memória (RUL, IV, n. 27, 23 jan. 1845, p. 330).

Não é possível saber se António Feliciano de Castilho chegou a visitar o estúdio ou se apenas ouviu o relato de uma visita. Não conhecemos nenhuma fotografia dele feita por Thiesson. Observamos, contudo, a atenção aos detalhes nessa crônica, como se o narrador tivesse realmente visto tudo aquilo. De uma forma ou de outra, mesmo não havendo nenhuma menção a datas no texto, sabemos que o redator poderia tê-lo incluído há mais tempo na Revista. Nele, o daguerreotipista comunica a seu modelo a necessidade de se conservar "imóvel por um terço de minuto, mas imóvel com a mais perfeita imobilidade", para que não saia defeituoso o retrato, complementando que isso "é o que torna extremamente difíceis os retratos de crianças, e dos pássaros; e impossíveis os das dançarinas e dos doidos" (RUL, IV, n. 27, 23 jan. 1845, p.330). Já no número da semana anterior, ao começar a análise do romance Eurico, de Alexandre Herculano, que acabara de ser publicado, Castilho alertava seus leitores da dificuldade de "pretender julgar um livro novo, novo na data da sua composição e novo também quanto ao género", pois a "impressão de uma primeira leitura sempre rápida [...] assemelha-se a um quadro de Daguerre representando objetos móveis; alguma luz, muitas sombras, contornos enleados, imagem exatíssima em partes, mas no todo perturbada" (RUL, IV, n. 26,16 jan. 1845 , p. 311). O crítico deve ter ouvido a descrição de um daguerreótipo de um objeto móvel do próprio Mr. Thiesson que figuraria na $R U L$ na semana posterior, ou de alguém que ouvira dele. A fotografia e o romance de Herculano são dois exemplos do que o século criava numa revista cheia do que o século destruía.

Porque triste fatalidade acontece que, depositando semanalmente para esta folha tamanho número de crimes e desgraças, raras vezes se nos deparem feitos ou ditos, que mereçam propostos ao respeito e à imitação?! Será porque o mal é comum e a virtude 
raríssima?! Os pessimistas assim o dizem; nós não o cremos. [...]

Já alguém nos acusou de tanto referirmos horrores, sem lhes entrecharmos cores mais alegres se não de longe a longe. Se nós fizéssemos novelas como fazemos coleção de elementos para estatística, muito peso teria a arguição: nós porém repetimos o que nos vem à noticia, e com melhor vontade aproveitamos sempre o bom e o louvável, do que o feio, repreensível e criminoso ( $R U L, \mathrm{IV}, \mathrm{n}$. 38, 10 abr. 1845 , p. 462).

António Feliciano de Castilho percebia um peso grande da literatura nas transformações da sociedade, por isso, prezava sempre por obras que fossem moralmente condizentes com um ideal de felicidade. Pelo que se nota em suas crônicas, apesar de serem em sua maioria sobre "o feio, repreensível e criminoso", não vinham nas folhas da Revista isentas de crítica. Há nesses textos uma tentativa civilizacional na busca de um ideal. Através de exemplos, positivos e negativos, da ironia, do aconselhamento ou do ataque direto a determinados usos e costumes, Castilho articulava para formar opiniões e, paulatinamente, moldar mentalidades e comportamentos. Como cronista de seu tempo ele poderia aproximar-se mais de seus leitores e, por conseguinte, aproximá-los dos temas e discussões que interessavam a ele como redator. $\mathrm{O}$ caminho apontado nesses textos é o da educação, o do trabalho, o da atenção do governo, o da paz, o da justiça, o do amor familiar; contra a presença ainda de superstições, enganos, da violência, da calúnia, dos excessos e, principalmente, contra aqueles que transformam tudo em cifras. É assim que, mesmo indiciando serem esses textos de impacto menor nas subjetividades do que a literatura, o jornalista não deixa de ser poeta, não deixa de ser utópico, não abre mão de seu papel social, ainda que em produções não destinadas a durar. O Castilho da crônica-folhetim é o homem atento ao cotidiano da Lisboa liberal. Seu olhar arguto foi uma contribuição valiosa para o aprimoramento das instituições, sem ignorarmos que há nele o homem do velho mundo também, apesar de defender sinceramente os ideais do século.

\section{Referências}

ALVES, Ida F. António Feliciano de Castilho: visitação a uma obra esquecida. In: ALVES, Ida; CRUZ, Eduardo da (Org.). Para não esquecer Castilho: cultura literária oitocentista. Niterói: EdUFF, 2014.
BARTHES, Roland. A Estrutura do Fait-Divers. In: BARTHES, Roland. Ensaios Críticos. Lisboa: Edições 70, 2009.

CAMÕES, Luís de. Os Lusíadas. Edição organizada por Emanuel Paulo Ramos. Porto: Porto Editora, 2000.

CANDIDO, Antonio. "A vida ao rés-do-chão" in: AAVV. A Crônica: o gênero, sua fixação e suas transformações no Brasil. Campinas: Ed. da Unicamp - Rio de Janeiro: Fund. Casa de Rui Barbosa, 1992.

CASTILHO, António Feliciano. Casos do meu tempo. Lisboa: Empreza da Historia de Portugal, 1906. Vol. I.

CASTILHO, António Feliciano. A Noite do Castello e Os Ciumes do Bardo. Poemas seguidos da Confissão de Amelia. Traduzida de M.elle Delfine Gay por A. Feliciano de Castilho. Lisboa: Typ. Lisbonense A. C. Dias, 1836.

CERTEAU, Michel de. A invenção do cotidiano: artes de fazer. Petrópolis: Vozes, 1998.

LÖWY, Michael; SAYRE, Robert. Romantismo e Política. Tradução de Eloísa de Araújo Oliveira. Rio de Janeiro: Paz e Terra, 1993.

MACHADO, Júlio César. Lisboa de Hontem. Lisboa: Empreza Litteraria de Lisboa, s.d.

MEYER, Marlyse. Folhetim: uma história. São Paulo: Companhia das Letras, 1996.

Revista Universal Lisbonense - Jornal dos Interesses Phisicos, Moraes e Litterarios. Colaborado por Muitos Sabios e Litteratos e Redigido por Antonio Feliciano de Castilho. Tomo I. Lisboa: Imprensa Nacional, 1842.

Revista Universal Lisbonense - Jornal dos Interesses Phisicos, Moraes e Litterarios. Colaborado por Muitos Sabios e Litteratos e Redigido por Antonio Feliciano de Castilho. Tomo II. Lisboa: Imprensa Nacional, 1843.

Revista Universal Lisbonense - Jornal dos Interesses Phisicos, Moraes e Litterarios. Colaborado por Muitos Sabios e Litteratos e Redigido por Antonio Feliciano de Castilho. Tomo III. Lisboa: Imprensa da Gazeta dos Tribunaes, 1844.

Revista Universal Lisbonense - Jornal dos Interesses Phisicos, Moraes e Litterarios. Colaborado por Muitos Sabios e Litteratos e Redigido por Antonio Feliciano de Castilho. Tomo IV. Lisboa: Imprensa da Gazeta dos Tribunaes, 1845.

RODRIGUES, Ernesto. Crónica Jornalística. Século XIX. Lisboa: Círculo de Leitores, 2004.

SILVEIRA, Jorge Fernandes. Fernão Lopes e José Saramago. Viagem - paisagem - linguagem. Cousa de veer. In: AAVV. A Crônica: o gênero, sua fixação e suas transformações no Brasil. Campinas: Ed. da Unicamp; Rio de Janeiro: Fund. Casa de Rui Barbosa, 1992.

Recebido: 27 de julho de 2016 Aprovado: 22 de maio de 2017 Contato: eduardodacruz@gmail.com 